\title{
Brand community integration and customer satisfaction of social media network sites among students
}

\author{
Hayford Amegbe $^{a^{*}}$, Henry Boateng ${ }^{\mathrm{b}}$ and Farouq Sessah Mensah ${ }^{\mathrm{c}}$
}

${ }^{a}$ Ph.D., Student, University of Nairobi, School of Business, Kenya

${ }^{b}$ University of Technology Sydney, Australia

${ }^{c}$ MPhil, Student, University of Cape Coast, Ghana

\section{CHRON I C L E A B S T RACT}

Article history:

Received: February 1, 2017

Received in revised format: July 6, 2017

Accepted: July 31, 2017

Available online:

August 2, 2017

\section{Keywords:}

Brand community (BC)

Customer satisfaction

Social media network sites (SNSs)

\begin{abstract}
The aim of the study was to examine how consumers integrate into brand communities on social media network sites (SNSs) and how it affects overall satisfaction of social media sites users among students. The study depends on the service-dominant logic (SDL) to develop the constructs for hypotheses testing. The study used a cross-sectional survey research design. The data were collected using a web-based survey of university of Nairobi Students. In all, a total of 608 students participated in the survey. The data was analyzed using structural equation modeling with AMOS software. The results revealed that frequency of usage of SNSs and duration of usage positively affect the self -perceived relevance of SNSs. Also, the self-perceived relevance leads to building brand community which finally leads to customer satisfaction. The research was limited to only students of Nairobi and selecting students in itself, which is a limitation as well as limiting it to university of Nairobi. The younger or the millennial are not the only users of SNSs. We have older generations as well, who also use SNSs for various activities such as professional development among others. Understanding why consumers of social media network site would integrate brand community is seminal for both local and foreign firms doing business in a developing country. This would enable marketing practitioners to craft marketing strategies best for community brand building.
\end{abstract}

\section{Introduction}

The concept of communities is not new to the academic scholarship. Earlier scholars (cf. Durkheim, 1893, 1933; Dewey, 1927; and Lasch, 1991) used to debate on this interesting subject during the nineteenth and early twentieth century. These earlier scholars like, Weber (1922, 1978), Gusfield (1978), Anderson (1983), Marshall (1994), Douglas and Ishwerwood (1979) provided us with the fundamental principles and concepts as well as an understanding of what community was all about. These scholars identified three main principles of community in the early days. The first seminal principle which was introduced by Gusfield was that communities were based on the consciousness of kind (and for more details commentary, see Muniz \& O'guinn, 2001). This principle from the perspective of * Corresponding author.

E-mail address: $\underline{\text { h.amegbe@students.uonbi.ac.ke (H. Amegbe) }}$ 
Weber (1978) means sense of belongingness. Secondly, the existence of rituals and traditions. The idea of rituals and traditions represent and symbolise their history, culture, and consciousness (Muniz \& O'guinn, 2001). Rituals "serve to contain the drift of meanings; ... [they] are conventions that set up visible public definitions" (Douglas \& Ishwerwood, 1979, p. 65). Conversely, traditions are defined as "sets of social practices which seek to celebrate and inculcate certain behavioral norms and values" (Marshall 1994, p. 537) and the last is the principle of moral responsibility. This principle talks about the sense of responsibility or obligation towards the collective interest of the entire community as well as the individuals within the community. During this era, communities were restricted by geography and were seen as a place, normally in a village or rural certain (see, Muniz \& O'guinn, 2001). Currently, the issue of communities is different due to advances in technology and the internet.

Moving on, in the extant literature, contemporary researchers like Muniz and O'Guinn (2001), Algesheimer et al. (2005); Leigh et al. (2006); Luedicke et al. (2010); McAlexander et al. (2002); Schouten et al. (2007) have advanced the work of earlier researchers on communities by extending it to brand communities and online communities. Among these researchers, Muniz and O'Guinn (2001) provided the foundation of brand communities among these contemporary researchers. Muniz and O'Guinn (2001) defined brand community as "a specialized, non-geographically bound community, based on a structured set of social relationships among admirers of a brand" (p.412). They indicated that the foundation of brand community is focused on three main pillars. The consumer, brand and consumer relationships where the brand is at the center stage of the community (Muniz \& O'Guinn, 2001). McAlexander et al. (2002) emphasised the relevance of the brand community as a way to understand customers' relationships and loyalty and the associated co-creation between consumers and firms. They were of the view that this consumer-centered relationship will result in emergence and construct around consumption experience. Examples of earlier communities studied in the scholarship of brand communities are virtual brand communities and include "The Apple Newton Community" (Muniz \& Schau,2005), "The Nikonians brand community" (Amine \& Sitz, 2004), "Basketball Shoes Community" (Füller et al., 2005). More importantly, issue rising from brand communities is consumer empowerment and the embedded consumers' role of value creation. Earlier on, researchers and marketers view brand community as geographically limited (cf. Schouten \& McAlexander, 1995, Celsi et al., 1993). These researchers provided us with insight into how consumers in these communities organize their lives and their identities. Meanwhile, Muniz, Jr., and O'Guinn (2001 p.412) suggested that community is defined as "specialized, non-geographically bound community, based on a structured set of social relations among admirers of a brand." Their observation about community is what most contemporary researchers (see, Judson et al., 2017) have extended it to the area of social media and social network sites (SNSs).

Currently, internet, social media (SM) and social network sites (SNSs) have altered how brand communities are formed and interact. Kaplan and Haenlein (2010) defined social media (SM) as "a group of Internet-based applications that build on the ideological and technological foundations of Web 2.0, and allow the creation and exchange of User Generated Content'" (p. 61). Kaplan and Haenlein (2010) noted that the user generated content (UGC) is usually created by consumers and widely available in the public domain with some level of creativity, though not with professional touch. This means that consumers can have $24 / 7$ access to these UGC through social media sites like blogs, microblogs, video/photo sharing sites, and social networks (Harris, 2009). Social network sites has been defined as "social network sites as web-based services that allow individuals to (1) construct a public or semipublic profile within a bounded system, (2) articulate a list of other users with whom they share a connection, and (3) view and traverse their list of connections and those made by others within the system"(Boyd \& Ellison, 2008, p.211). The introduction of web 2.0 and UGC have today changed the way marketing strategies are implemented more than ever. The academic scholarship (cf. Corstjens \& Umblijs, 2012) suggest that companies who would take advantage of the benefits of social media presence by connecting their customers, employees and other stakeholders will remain competitive and 
successful than their counterparts. For example, according to the 2016 social media marketing industry report (SMMIR), p. 6, the top five major concern of marketers on social media usage in the order of priority are; tactics, engagement, measurement, audience, and tools. Succinctly explained, marketers, wish to know which tactics work for them best, how to engage customers on social media, how to measure the return on investment on social media, how to target the users or the audience on social media and lastly the best social media tool to use. These are the challenges confronting marketing practitioners today as social media is continuously impacting on their business. Though, social media present challenges, marketers also admitted using social media and social media network sites have brought benefits to their businesses. Referring to the 2016 social media marketing industry report p.7, ninety percent $(90 \%)$ admitted the importance of social media to their business and academic scholars ( cf. Judson et al. 2017; Devasagayam \& Bluff, 2012) have also found the importance of social media to the success of organisations. In the 2016 SMMIR p.17, reveals benefits such as image exposure, increased traffic, loyal customers, generating leads, improved sales, reduction in marketing expenses, the growth of business partnerships are some of the benefits of using social media and social media network sites (SNSs).

The extant literature on brand community (for more commentary, (e.g. Judson et al., 2017; Devasagayam \& Bluff, 2012) acknowledged integration customers into brand communities as a way of exploiting the benefits, social media present in general. Judson et al. (2012) observed integrating customers into brand community enhance customer satisfaction, brand image, relationship building and the overall marketing strategy. As noted among scholars, customer satisfaction of a brand has implication for financial success and the general performance of an organisation. The current brand communities emerging on various social media network sites (SNSs), present opportunities which most organisations are yet to take advantage of, by engaging these communities in creating values that would enhance the image of their brands. The most valuable assets of every business today is the customer (de Waal et al., 2016). De Waal et al. (2016) suggested that customer retention is the only guarantee for the survival of any organisation today. There is no doubt that integrating customers into brand communities would present several opportunities for organisations to take advantage of. Despite the opportunities that comes with integrating customer into brand communities noted in the academic literature, most companies in Kenya and other developing countries are yet to take advantage of these opportunities. This is because most of the studies (e.g., Judson et al., 2017; Devasagayam \& Bluff, 2012; Kaplan \& Haenlein, 2010; Boyd \& Ellison, 2008, p.211 ) have looked at social media in general and particularly in developed countries. Yet, the literature lacks empirical evidence on brand integration when it comes to developing countries perspective especially Kenya. This makes the study so important and timely by contributing to the paucity of academic literature on brand community integration on social media network sites. Secondly, the study brings to the attention of marketing practitioners on how they would be able to formulate strategies which would integrate consumers into their social media network sites to enhance customer satisfaction, brand image for them to remain competitive and profitable. The main objective of this study is to investigate brand community integration and customer satisfaction of social media network sites (SNSs) among students. To address this objective we developed sub-objectives which are 1) to determine whether frequency (FRQ) of SNSs predicts relevance (RELV) of SNSs and also duration (DURA) of stay on SNSs predicts the relevance of SNSs. 2) to determine whether RELV predicts brand community (BC) and 3) whether BC and RELV predict overall customer satisfaction (CSALT). To examine these relationships we developed and tested (see Fig. 1) the constructs of integrating brand community and satisfaction of social media network sites (SNSs).

Moving on, scanning through the community branding literature the study observed that scholars like Tajfel and Turner (1985), Bourdieu (1983), Coleman (1988), Vargo and Lusch (2004, 2008) and Judson et al. (2016) have used theories such as dominant logic of marketing (S-D logic), social identity theory, and theory of social capital to examine BC. However, this study, relied on the S-D logic theory by Vargo and Lusch, $(2004,2008)$ which was also used by Judson et al. (2016) in a similar study to examine brand integration and customer satisfaction of users of social media sites. S-D logic views the 
service dominance as a whole business process which emphasises the intangible value to create core competencies, skills and knowledge, and the co-creation of value (Vargo \& Lusch, 2004a). Vargo and Lusch (2004a) indicated that firms need to depend on their core competencies to co-create value with consumers, the interaction between companies and consumers, in other to create a value proposition.

Researchers in the past have focused on the benefits of brand communities from the business perspective, interactions between community members, or the relationship between shared consciousness and community commitment (McAlexander et al., 2002; Muniz \& O'Guinn, 2001; Thompson \& Sinha, 2008). Little is known about how companies should integrate with these brand communities on (SNSs) to co-create values which would satisfy customers and eventually lead to enhance brand image. For a customer to be attracted to a particular social media (SM), ogranisations should have some activities and programes that would attract and engage the customer on their site for a long time. Organisations should do everything for customers to engage with them on their SNSs. Researchers like Judson et al. (2012) have shown that when customers frequently visit a particular website and spends more time on visiting it, they perceive the site as relevant to them. The more relevant the sites are to them, the more they become part of that community and can interact and engage with other customers and the organisation. As this relationship is developed, researchers (e.g. Clark et al., 2017; Judson et al., 2012) have observed that when organisations take advantage of this and developed the relationship well, it leads to customer satisfaction and loyalty which build a strong brand for the organisation. Having said, the rest of the paper is organised as follows: 1) an overview of brand community, satisfaction, and social media, 2) contextualization, 3) conceptual framework and hypothesis testing, 4) methodology, 5) discussion and 6) conclusion.

\section{Brand community (BI), Online brand communities (OBC), social media network sites (SNSs), and satisfaction (SAT): An overview}

The idea of community has been the focused of sociological and anthropological theory since Tönnies (1887) differentiated society from community (Brint, 2001). The term "society" is defined as a social group built on a social contract, while "community" is defined as a group of individuals gathered by emotional and organic links. The preoccupation of community was considered as a group of individuals who share a particular geographical area and have frequent interactions among themselves (Brint, 2001). This concept reveals that communities were geographically limited in their interaction among themselves.

Currently, with the burgeoning of the internet, the issue of geographical trammel of communities have been removed, and communities can be formed and interact irrespective of their geographical location in the world. Also, it has become easier today to bring people from all walks of life together (Kollock $\&$ Smith, 1999). These interactions and relationships are considered as a social network. Through the use of the internet, activities which traditionally, customers would have performed offline can also be performed online today. With the introduction of the internet, social media network has gained grounds in several consumer behavioral theories in the academic domain. The internet has changed the orthodox communities today. The internet has facilitated the emergence of brand community which gradually replaces the traditional communities.

Researchers have studied this new brand community and defined it as "a specialized, nongeographically bound the community, based on a structured set of social relationships among admirers of a brand"(Muniz et al., 2001, p.412). They indicated that the focus is on branded goods or service which makes it special. Further, they compared it to other communities and stated that brand communities had shared consciousness, rituals, and traditions and a sensed of moral responsibility. Previous researchers in the ethnographic fieldwork of subcultures of consumption among bikers (Schouten \& McAlexander, 1995) and skydivers (Celsi et al., 1993) served as the premise for scholars 
to appreciate how consumers organize their lives and identities. McAlexander et al. (2002) state that, "a brand community from a customer-experiential perspective is a fabric of relationships in which the customer is situated.". According to McAlexander et al. (2002, p. 38) "Crucial relationships have typically included those between the customer and the brand, between the customer and the firm, between the customer and the product in use, and among fellow customers". It is unlikely for a customer to switch to another brand if the relationship with an organisation is bonding. The implication is that it enhances the brand positively. Building strong ties with customers is of numerous advantages for an organisation. When these relationships are fostered and sustain, the organisation can achieve competitive advantage for the brand which is difficult for competitors to copy.

A study conducted by Pew Internet Research (2014) observed that $74 \%$ are in contact with social media network sites (SNSs). SNSs has been defined as "web-based services that allow individuals to (1) construct a public or semi-public profile within a bounded system, (2) articulate a list of other users with whom they share a connection, and (3) view and traverse their list of connections and those made by others within the system" (Boyd \& Ellison,2008, p. 211). SNSs are now a dual role of connecting people. According to Ellison et al. (2007, p. 1144) "online SNSs support both the maintenance of existing social ties and the formation of new connections". In another study conducted by Pew Internet Research (2014) it was revealed that as of January 2014, 19\% of online adults use Twitter, September 2013, 71\% adults use Facebook, 17\% use Instagram, 21\% use Pinterest and $22 \%$ use LinkedIn. This suggests that SNSs usage is on the increase and the time have come for marketers to understand these social behaviours on these SNSs to enable them to build brand communities which would enhance their brands. Satisfaction is the key in the engagement and relationship building among SNSs in building brands. A study conducted by Clark et al. (2017) using S-D logic theory examined 108 undergraduate students on the use of (SNSs) and satisfaction, the result shows that consumers are likely to integrate into a brand community if they see the site as personally relevant. Clark et al. (2017) indicated that for the site to be relevant, two issues are vital. The frequency of visit to the SNSs and the duration of stay. Similar studies conducted by Judson et al. (2012) on self-percieved brand relevance and satisfaction of social media revealed that the perception of relevance of a given social media to the respondent depends on the frequency of use and the duration of each visit.There is an evidence in the extant literature which suggests that the frequency of SNSs and duration of stay contributes to the relevance of the sites. When customers perceived the SNSs to be relevant and meeting their needs, they would turn to feel part or integrated into that community, and this situation could lead to customer satisfaction and eventually brand image enhancement. That is why it is important for marketers to encourage the integration of customers into their SNSs so that they can be satisfied. Researchers have also observed that when a customer is satisfied, they become loyal. When customers are loyal, this could translate into financial success for the organisation. That is why it is imperative for organisations to pay attention to their brand communities and integrated them into their SNSs.

\subsection{Conceptual Framework}

The study from the extant literature developed the conceptual framework (see, Fig. 1) in testing the hypotheses. As observed by similar studies conducted in different developed countries, the study argues that organisations SNSs would be perceived as more relevant to customers based on the frequency of visit and the duration of stay on the SNSs of the organisation. When customers turn to like the organisations page and interact more with the organisation, then it becomes relevant to them. Secondly, when customers feel that the SNSs of an organisation is more relevant to them, they are more likely to feel part of the organisation and can integrate into the brand community of the organisation. The study is of the view that, the more customers feel they are part of a brand community and the brand community meets their expectations and needs, the more satisfied they become ((Judson et al., 2012). Researchers Clark et al. (2017), Judson et al. (2012) noticed that when customers are satisfied this leads to customers being loyal to the organisation, and this contributes to the financial success of the organisation. The framework did not extend to test whether satisfaction leads to customer loyalty. The 
framework was grounded on the S-D logic theory which was also used by Clark et al. (2016) in similar studies. Fig. 1 presents the conceptual framework used for the study.

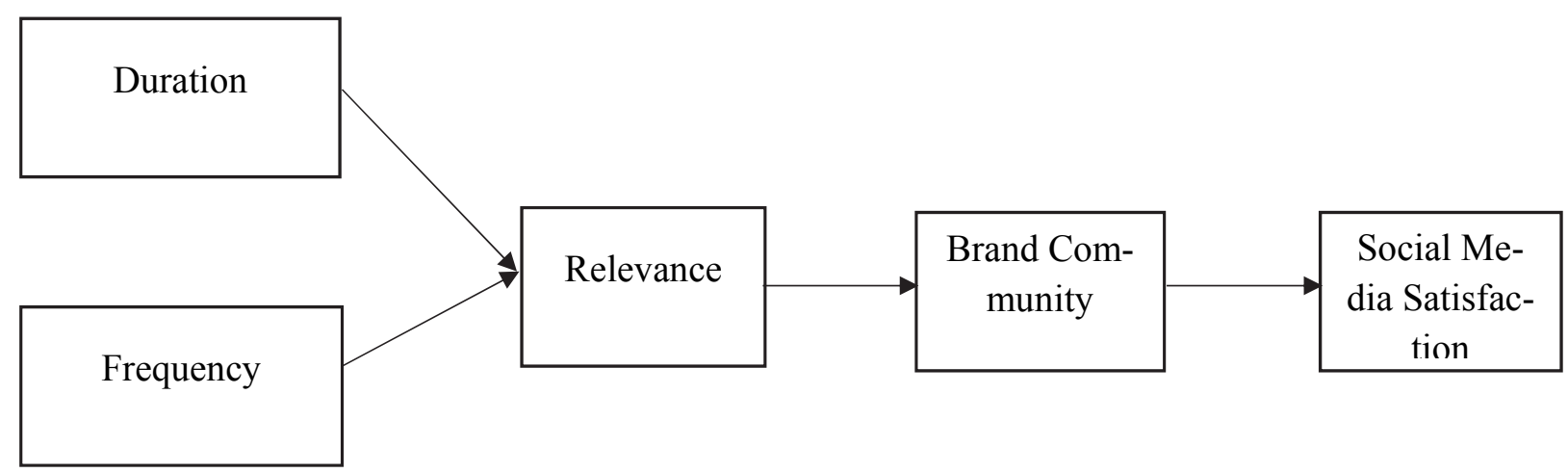

Fig. 1. Conceptual Framework

\subsection{Hypothesis Testing and Development}

Since the study was grounded in the S-D logic theory, the study discusses its contribution towards our hypothesis development and testing. The s-d logic theory is a new of way of marketing thought. The theory views marketing as consumer-centric or service-centric rather than firm-centric or good-centred (Vargo \& Lusch, 2004a). Bradshaw and Schroeder (2008) indicated that the concept is focused on two main ideas of operant and operand resources borrowed from resource-based theory. They reported that the operand resources are the factors of production resources such as raw materials or goods used to produce effects which is the primary focus of good-centred firm. Conversely, the operant is viewed from service-centred as sense-and-response in order to leverage from competitive advantage to outperform competitors. In this new way of thought, the S-D logic theory posits that organisations should be concerned with understanding how consumers engage in value creation process by looking at the consumer as the operant resource. Bradshaw and Schroeder (2008) indicated that organisations have to employ their core competencies to co-create value with consumers, the interaction between firms and consumers, in order to create a value proposition. To understand the co-creation of value is by asking how consumers engage in this process. (Fournier, 1998), brand community is a social phenomenon which is constructed from the dyad relationship between consumers and brands, and evolve from interaction among consumers to create a group or real community around a specific brand. Hence, our use of S-D logic theory to investigate how organisations could develop this relationship by integrating their customers into their SNSs in building brand community which will lead to customer satisfaction and eventually enhance their brands. Having discussed the S-D theory we now attention to discussing the various hypotheses to be tested by our study.

The first two hypotheses are formulated as H1: Frequency (FRQ) will be positively associated to relevance (RELV) and H2: Duration (DURA) will be positively associated with relevance (RELV). Empirical study conducted by Clark et al. (2017), of 108 undergraduate students of a large university in the Midwest USA and at a mid-sized university in the Mid-Atlantic USA on brand community and social media satisfaction revealed that relevancy was affected by the frequency with which the consumer visits the site, however, they did not find duration of stay on the SNSs to be relevant. Meanwhile, a similar study conducted by Judson et al. (2012) in the USA using 432 undergraduate students from two large, public Midwestern universities on self-percieved brand relevance and satisfaction of social media showed otherwise. Their results indicated that the perception of relevance of a given social media to the respondent is dependent on frequency of use and the duration of each visit. So far, the two empirical studies conducted revealed different results as far us how frequency and duration impact on the relevance of a SNSs. That is why the study is important for us to also test these 
constructs in a different country context to see if a different outcome will emerge. There seems to be no agreement between the two constructs; frequency of visit and duration of stay impacting on the perceived relevance of SNSs, simultaneously. Also, Kabadayi and Price (2014) posit that customer engagement on social media may manifest itself in many ways, including frequency of visits, duration of visits as well as "liking" and commenting on various posts. Based on the above extant review the study proposed the following testable hypotheses.

\section{H1: FRQ will be positively associated to RELV}

\section{H2: DURA will be positively associated with RELV.}

Social interaction with others typically happens through online communities; engagement in these communities leads to more informed and better purchasing decisions online (Hajli, 2015a). A study by Hajli (2015) shows that social commerce constructs are more likely to "attract individuals, increase trust and influence consumers' intention to buy" (Hajli, 2015b, p. 189). For example, Wang and Hajli (2014) found that social commerce had a positive impact on social support, relationship quality and co-branding. Marketers should be able to take advantage of this trend, by evaluating the performance of their investment in SM marketing. Focusing on brand communities can help marketers in addressing the issue of performance evaluation in SM marketing. Also, strategies for managing brand communities can represent a potential source of competitive advantage for firms (Pihl, 2014). SM is conceptualized on the idea of engagement, utilizing two-way communication. Researchers (Clark et al., 2017; Judson et al., 2012) have shown that the more customers of an organisation perceived SNSs to be relevant, the more they are likely to be part of that brand community. Once they can interact and engage with the SNSs of the organisation and the organisation is also able to develop content which would meet their expectations they become bonded to the SNSs, and they integrate into that brand community. When customers feel integrated and part of a brand community and when their needs are met they become satisfied. Customers are open to the brand once they feel that they are part of the brand community. Organisations can well integrate customers into their SNSs, by building and developing the triadic relationship between the customer-customer, brand and the organisation, would ultimately lead to customer satisfaction. As suggested by Goh et al. (2013) consumers and marketers alike play an influential role in developing relationships in social media environments. Based on the above the next hypotheses are formulated as follows:

H3: RELV will be positively associated with BC

H4: $B C$ will be positively associated CSALT

H5: There will be differences among social media sites on the dependent variables

\subsection{Sample and data collection}

A sample of 608 students who were social networking sites users, and followed at least a brand on social media platforms were randomly selected from the population. The choice of this sample size is considered for the study as determined by Krejcie and Morgan (1971) table for determining sample size from a given population. This sample size is considered relatively large, reasonably adequate and representative of the population. Random sampling technique was used because it gives the elements of the population equal opportunity of being part of the sample and also to reduce the potential for human bias in the selection of cases to be included in the sample. The large sample size addresses the issue of common method bias since single respondent bias is eliminated as aggregated responses

have a central tendency towards the mean (Cooper \& Emory, 1995). Students were selected as the sample because of their familiarity with and frequent use of social media (Barnes \& Mattson, 2010). The results of the study (Table 1), showed that the ratio of male to female is almost 50: 50 . The majority of the respondent representing $85.0 \%$ out the sample were aged between 18 and 25 years (Table 1). 
The level of students indicated that preponderance of the respondent were in their final year representing $31.1 \%$ (Table 1). All participants were social media users. However, the intensity of social media usage varied among different participations and social media network site. The majority of the respondent representing $85.7 \%$ use social media for over 5 times in a day and for an average time of 3 hours each time and mostly on Instagram. In all, 683 students participated in the study. However, only 608 questionnaires were usable for the study because they turned out to be entirely completed questionnaires.

\subsection{Measures}

The measures for the study were from relevant extant literature. Consumers' duration of use, frequency of usage, satisfaction and their self-perceived relevance of social media sites were adapted from previous research by Judson et al. (2012). Also, brand community was measured with an established brand community scale (Devasagayam \& Buff, 2012) consisting of 11 questions on a five-point Likert scale ranging from strongly agree to disagree strongly.

Table 1

Demographic Characteristics

\begin{tabular}{lll}
\hline Demographic Variables & Frequency & \% \\
\hline Gender & & \\
\hline Male & 301 & 49.5 \\
Female & 307 & 50.5 \\
\hline Total & $\mathbf{6 0 8}$ & $\mathbf{1 0 0 . 0}$ \\
\hline Age & & 85.0 \\
\hline $18-25$ & 517 & 12.0 \\
$26-30$ & 74 & 2.8 \\
\hline $1-35$ & 17 & $\mathbf{1 0 0 . 0}$ \\
\hline Total & $\mathbf{6 0 8}$ & 27.1 \\
\hline Level & & 16.1 \\
\hline Level 100 & 165 & 25.7 \\
Level 200 & 98 & 31.1 \\
\hline Level 300 & 158 & $\mathbf{1 0 0 . 0}$ \\
\hline Level 400 & 189 & \\
\hline Total & $\mathbf{6 0 8}$ & \\
\hline
\end{tabular}

Source: Field Data, 2017

\subsection{Reliability and validity of measures}

To assess the initial reliability of the measures, Cronbach's alpha for all the construct was calculated and found to be 0.91. Next, a confirmative factor analysis (CFA) was applied on the measures used in the study. A structural equation modeling was employed for the confirmatory factor analysis and path analyses. The researchers followed the two-step approach recommended by Anderson and Gerbing (1988). In the first stage, the measurement model was analyzed to ensure sufficient reliability and validity of the constructs. In the second stage, the hypotheses of the relationships between constructs were tested. Model fit criteria suggested by Hu and Bentler (1999) were used for both the measurement and the structural model: $x^{2} / d f$, goodness of fit (GFI), adjusted goodness of fit (AGFI), comparative fit index (CFI), root mean square residual (RMR), and root mean square error of approximation (RMSEA). Acceptable models should have $\left(x^{2}\right) / d f \leq 3, A G F I \geq 0.80, R M R \leq 0.10, R M S E A \leq 0.10$ and GFI and CFI greater than 0.90. Patterns fitting indicators are listed in the Table 2. Table 2 indicated that all criteria met the recommended values in the measuring patterns and related Factor loadings were all 
more than 5\%, and the significance level is 0.000 . For discriminant validity, the study calculated $95 \%$ confidence intervals of the correlations among constructs. None of them includes 1, which supports discriminant validity (Bagozzi, 1994).

Table 2

Measuring patterns fitting overall indicators

\begin{tabular}{llllll}
\hline Construct/Indicators & FRQ & DUR $\boldsymbol{A}$ & $\boldsymbol{R E} \boldsymbol{L} \boldsymbol{V}$ & BC & CSALT \\
\hline CMIN/DF & 1.38 & 1.84 & 1.64 & 2.01 & 1.15 \\
RMR & 0.02 & 0.01 & 0.01 & 0.02 & 0.01 \\
GFI & 0.74 & 0.83 & 0.72 & 0.84 & 0.73 \\
AGFI & 0.84 & 0.92 & 0.93 & 0.83 & 0.81 \\
IFI & 0.85 & 0.89 & 0.91 & 0.95 & 0.84 \\
CFI & 0.76 & 0.81 & 0.89 & 0.93 & 0.93 \\
\hline
\end{tabular}

Source: Field Data, 2017

\subsection{Structural Model}

According to the research hypotheses, a structural equation modeling was developed to assess the statistical significance of the proposed relationships among social media sites. Structural equation modeling was chosen by the researchers to analyze the data due to its ability to analyze multiple equations at once. Table 3 shows the model overall fittings indicators. Amos output results (Table 3) in model standard estimation section indicate that path analysis model is a suitable model. CMIN/df is 1.87 which is acceptable. RMSEA rate is equal to 0.01 which is appropriate, GFI and AGFI and other four variables of NFI, CFI, TLI and IFI rate are all more than $80 \%$. Moreover, finally RMR rate indicates approximately zero. Fitting indicators for all patterns is in the acceptance area, and these indicators reveal a good pattern fitting by data and the collected data support the pattern well.

\section{Table 3}

The Model Fitting Indicators

\begin{tabular}{ll}
\hline Variables & Indicators \\
\hline RMR & 0.001 \\
PCFI & 0.73 \\
IFI & 0.98 \\
CFI & 0.87 \\
TLI & 0.91 \\
NFI & 0.92 \\
AGFI & 0.94 \\
GFI & 0.86 \\
RMSEA & 0.01 \\
CMIN/df & 1.87 \\
\hline
\end{tabular}

Source: Field Data, 2017

Apart from the model's general fit for the data, its parameters were tested to decide whether to accept the proposed relationships between exogenous and endogamous constructs (Hair et al., 1998). The results for the frequency, duration, relevance, brand community and satisfaction of social media sites are shown in Table 4.

\section{Table 4}

Results of hypotheses testing

\begin{tabular}{clllll}
\hline Hypothesis & Relationship & Standard coefficient & t-value & p - value & Results \\
\hline $\boldsymbol{H}_{\mathbf{1}}$ & FRQ - Self-perceived RELV & 0.43 & 3.84 & $\leq 0.001$ & Supported \\
$\boldsymbol{H}_{\mathbf{2}}$ & DURA - Self-perceived RELV & 0.41 & 3.02 & $\leq 0.001$ & Supported \\
$\boldsymbol{H}_{\mathbf{3}}$ & Self-perceived RELV - BC & 0.48 & 3.41 & $\leq 0.001$ & Supported \\
$\boldsymbol{H}_{\mathbf{4}}$ & BC - CSALT & 0.42 & 3.16 & $\leq 0.001$ & Supported \\
\hline
\end{tabular}


The four hypotheses which relate to frequency - self-perceived relevancy, duration - self-perceived relevancy, self-perceived relevancy - brand community, and brand community - satisfaction were all accepted.

Hypothesis five $\left(H_{5}\right)$ was tested using ANOVA since the analysis required researchers to compare means among groups. The analysis indicated that there is a significant difference among social media sites on frequency, duration, relevance, brand community and satisfaction with the significance level at $p<0.05$.

Table 5

\begin{tabular}{|c|c|c|c|c|c|}
\hline Variable & Sum of Squares & df & $\begin{array}{c}\text { Mean } \\
\text { square }\end{array}$ & $F$ & Significance \\
\hline \multicolumn{6}{|l|}{ FRQ } \\
\hline Between groups & 64.342 & 3 & 21.327 & 9.341 & 0.011 \\
\hline Within groups & 198.387 & 604 & 1.431 & & \\
\hline Total & 262.729 & 607 & & & \\
\hline \multicolumn{6}{|l|}{ DURA } \\
\hline Between groups & 41.211 & 3 & 11.431 & 6.971 & 0.031 \\
\hline Within groups & 182.471 & 604 & 1.108 & & \\
\hline Total & 223.682 & 607 & & & \\
\hline \multicolumn{6}{|l|}{ RELV } \\
\hline Between groups & 7.567 & 3 & 2.338 & 2.004 & 0.010 \\
\hline Within groups & 143.043 & 604 & 1.593 & & \\
\hline Total & 150.610 & 607 & & & \\
\hline \multicolumn{6}{|l|}{ BC } \\
\hline Between groups & 441.530 & 3 & 121.144 & 2.912 & 0.022 \\
\hline Within groups & 703.193 & 604 & 61.634 & & \\
\hline Total & 1145.323 & 607 & & & \\
\hline \multicolumn{6}{|l|}{ CSALT } \\
\hline Between groups & 147.921 & 3 & 42.529 & 5.328 & 0.017 \\
\hline Within groups & 903.081 & 604 & 7.943 & & \\
\hline Total & 1051.731 & 607 & & & \\
\hline
\end{tabular}

Source: Field Data, 2017

\section{Discussion of Results}

In the marketing literature, scholars Clark et al. (2016) and Judson et al. (2012) have researched into branding and customer satisfaction and the use of social media using the S-D logic theory. Their findings (Judson et al., 2012) indicated that frequency of visit of customers and duration of stay on SNSs impact on the relevance of the SNSs of an organisation and when managed well by an organisation could lead to a customer been integrated into the brand community. Also, when a customer is integrated into a brand community this also leads to customer satisfaction and as well as loyal to the organisation. However, a similar study by Black and Judson (2017) did not find duration of stay on SNSs contributing to the relevance of the SNSs. The findings are, however, consistent with the study conducted by Judson et al. ( 2012). The result of the study revealed that frequent visit and duration positively impact on the relevance of SNSs, and relevance impact on brand community and finally brand community leading to customer satisfaction. The result indicated that H1: FRQ - RELV, H2: 
DURA - RELV, H3: RELV - BC were all supported. The more frequent (FRQ) customer visit and the more time (DURA) they spent makes the SNSs site more relevant to them. This engagement on the SNSs enables users to feel and be part of brand community. When this community is developed and is frequently engaged by marketers, this makes customers become satisfied. Our corollary shows that when customers (H4: BC - CSALT) are part of brand community, they are satisfied.

Based on the customer service-dominant logic theory S-D theory, it was noticed that the more frequent customers visit SNSs and the longer they stay they are likely to be integrated into the brand community of that site, and when they feel part of the community they are likely to be satisfied. Theoretically, the study contributes to the development of the key concepts of customer co-creation value and engagement indicated by the S-D theory. The present results also support how customers are more inclined to integrate into a brand community. A look at the constructs of customer engagement behaviour on SNSs would be wealth researching into. Organisations could also look at how to drive customer engagement behaviours from their point of view instead of the customers perspective. Is expedient for organisations to understand these behaviour driven influences to enable them to take advantage of the brimming opportunities of SNSs targets. The study presents the initial stage of understanding brand community integration on SNSs and satisfaction for marketers especially in developing context to use the result to formulate strategies and in making decisions. It is important to note that integrating customers into their SNSs contributes to satisfaction with their brands. The findings also revealed that frequent visit is necessary when it comes to RELV, this leads to brand community integration and finally CSALT. Marketing managers should, therefore, encourage a frequent visit to their SNSs through marketing programs which would necessitate frequent visit. This would help in integrating their customers into their brand communities which would enhance the brand image. Practically, the study offers a good insight for organisations seeking to build brand community and increase customer satisfaction through SNSs will be able to use the results of the present study to make informed decisions regarding the type of SNSs to use. Also, spending time and effort in building brand communities helps customers integrate into a brand community which contributes to making the customers more satisfied with the brand. Marketers could look at organising sales promotion online for their customer. This would lead to routine visit which would engage customers into integrating into their brand community in building their brand. For marketing practitioners, the study shows how spending time and resources in building brand communities help in satisfying customers. This means that those who would understand and work towards building these brand communities would eventually be the winners of the day. Marketers are also aware of the benefits of a satisfied customer to their business. The results of the study also supported H5 which indicated that there is a significant difference among SNSs on frequency, duration, relevance brand community and satisfaction

\section{Limitations and Future Research}

The researchers acknowledge that the study has some limitations that readers should take note of when reading. The first limitation is that the survey was limited to only students of the University of Nairobi, which in itself makes a generalisation of our findings impossible. Secondly, the study focused on the millennial group. Though they are the preponderance when it comes to the usage of SNSs; there are people beyond the millennials who also use SNSs. Perhaps, combining these two groups from different demographic backgrounds could bring a different perspective to the study. Future research could look at older generation and brand community building and integration. Currently, most of the SM research is focusing on the younger generation. A study is urgently needed to know some of the behavioural characteristics of the older generation and the usage of SNSs. Secondly, understanding how companies could take advantage of how word-of-mouth and brand community interrelationship would not be a bad idea. Word-of-mouth has in extant literature has shown to contribute to building and to enhance the image of a brand. From the online point of view, a study into word-of-mouth has become imperative. 


\section{References}

Algesheimer R, Dholakia, UM, Hermann, A. (2005). The social influence of brand community: evidence from European car clubs. Journal of Marketing, 69 19-34.

Amine, A., \& Sitz, L. (2004). How does a virtual brand community emerge? Some implications for marketing research. Research Paper, University Paris.

Anderson, J. C., \& Gerbing, D. W. (1988). Structural equation modeling in practice: A review and recommended two-step approach. Psychological bulletin, 103(3), 411.

Anderson, B., (1983). Imagined Community, London: Verso..

Bagozzi, R.P., (1994). Principles of marketing research, Blackwell Publishers, Cambridge.

Barnes, N. G., \& Mattson, E. (2010). Social media and college admissions: Higher-ed beats business in adoption of new tools for third year. University of Massachusetts-Dartmouth Center for Marketing Research.

Brint, S. (2001). Gemeinschaft revisited: A critique and reconstruction of the community concept. Sociological theory, 19(1), 1-23.

Boyd, D.M. \& Ellison, N.B. (2008). Social network sites: definition, history, and scholarship. Journal of Computer-Mediated Communication, 13(1), 210-230

Bourdieu, P., (1983), Forms of Capital, in Richardson, JG (eds.). Handbook of Theory and Research for the Sociology of Education. New York: Greenwood.

Celsi, R.L., Rose, R.L. and Leigh, T.W., (1993). An exploration of high-risk leisure consumption through skydiving. Journal of consumer research, 20(1) 1-23.

Clark, M., Black, H.G., \& Judson, K., (2017). Brand community integration and satisfaction with social media sites: a comparative study. Journal of Research in Interactive Marketing, 11(1) 39-55.

Coleman, J.S., (1988). Social capital in the creation of human capital. American journal of sociology, 94, 95-120.

Cooper, D.R. \& Emory, C.W., (1995). Business Research Methods, Chicago: Richard D. Irwin. Inc.

Corstjens, M., \& Umblijs, A. (2012). The power of evil: The damage of negative social media strongly outweigh positive contributions. Journal of Advertising Research, 52 (4), 433-449

Devasagayam, P.R. \& Buff, C., (2005). Exploring the generalizability of the brand community construct: application in sports marketing. In Exploring New Frontiers in Marketing, 2005 Annual Conference Proceedings of Marketing Management Association (pp. 63-73).

Devasagayam, P.R., Buff, C.L., Aurand, T.W. and Judson, K.M., (2010). Building brand community membership within organisations: a viable internal branding alternative?. Journal of Product and Brand Management, 19(3), 210-217.

de Waal, A., \& van der Heijden, B. (2016). Increasing customer loyalty and customer intimacy by improving the behavior of employees. Journal of Strategy and Management, 9(4), 492-510.

Dewey, J., (1927). The Public and Its Problems (New York: H. Holt \& Co.).

Douglass, M. and Isherwood, B., (1979). The World of Goods.

Durkheim, E. (1933). The division of labor in society, trans. George Simpson. New York: Free Press.

Ellison, N.B., (2007). Social network sites: Definition, history, and scholarship. Journal of ComputerMediated Communication, 13(1), 210-230.

Ferdinand, T.Ö.N.N.I.E.S., (1887). Gemeinschaft und Gesellschaft, english tr.(1957). Community and Society.

Fournier, S., (1998). Consumers and their brands: Developing relationship theory in consumer research. Journal of consumer research, 24(4), 343-373.

Füller, J., Jawecki, G. and Mühlbacher, H., (2007). Innovation creation by online basketball communities. Journal of Business Research, 60(1), 60-71.

Goh, K.Y., Heng, C.S. and Lin, Z.,(2013). Social media brand community and consumer behavior: Quantifying the relative impact of user-and marketer-generated content. Information Systems Research, 24(1), 88-107.

Gusfield, J. 1978. Community: A critical response. New York: Harper and Row.

Hair, J.F., Black, W.C., Babin, B.J., Anderson, R.E. and Tatham, R.L., (1998). Multivariate data 
analysis (Vol. 5, No. 3, pp. 207-219). Upper Saddle River, NJ: Prentice hall.

Hajli, N.,(2015). Social commerce constructs and consumer's intention to buy. International Journal of Information Management, 35(2), 183-191.

Harris, R., (2009). Social media ecosystem mapped as a wiring diagram.

Hu, L. and Bentler, P.M. (1999). Cutoff criteria for fit indexes in covariance structure analysis: conventional criteria versus new alternatives. Structural Equation Modeling, 6(1), 1-55

Judson, K.M., Devasagayam, P.R. and Buff, C.L., (2012). Self-perceived brand relevance of and satisfaction with social media. Marketing Management Journal, 22(2), 131-144.

Kabadayi, S. and Price, K.,( 2014). Consumer-brand engagement on Facebook: liking and commenting behaviors. Journal of Research in Interactive Marketing, 8(3), 203-223.

Kaplan, A.M. and Haenlein, M., (2010). Users of the world, unite! The challenges and opportunities of Social Media. Business horizons, 53(1), 59-68.

Kollock, P., (1999). The economies ol online cooperation. Communities in cyberspace, 220.

Krejcie, R.V. and Morgan, D.W., (1970). Determining sample size for research activities. Educational and psychological measurement, 30(3), 607-610.

Lasch, C., (1991). The true and only heaven: Progress and its critics. WW Norton \& Company.

Leigh, T.W., Peters, C. and Shelton, J., (2006). The consumer quest for authenticity: The multiplicity of meanings within the MG subculture of consumption. Journal of the Academy of Marketing Science, 34(4), 481-493.

Luedicke, M.K., Thompson, C.J. and Giesler, M., (2009). Consumer identity work as moral protagonism: How myth and ideology animate a brand-mediated moral conflict. Journal of Consumer Research, 36(6), 1016-1032.

Marshall, G., (1994). The Concise Oxford Dictionary of Sociology, Oxford: Oxford University Press.

McAlexander, J.H., Schouten, J.W. and Koenig, H.F., (2002). Building brand community. Journal of marketing, 66(1), 38-54.

Muniz, A.M. and O'guinn, T.C., (2001). Brand community. Journal of consumer research, 27(4), 12432.

Muniz Jr, A.M. and Schau, H.J., (2005). Religiosity in the abandoned Apple Newton brand community. Journal of consumer research, 31(4), 737-747.

Pew Internet Research, (2014). Social networking fact sheet", available at: www.pewinternet.org/factsheets/social-networking-fact-sheet/

Pihl, C., (2014). Brands, community and style-exploring linking value in fashion blogging. Journal of Fashion Marketing and Management, 18(1), 3-19.

Pongsakornrungsilp, S., Bradshaw, A. and Schroeder, J.E., (2008). Brand community as co-creation value in the service-dominant logic of marketing.

Jensen Schau, H. and Muniz Jr, A.M., (2006). A tale of tales: the Apple Newton narratives. Journal of Strategic Marketing, 14(1), 19-33.

Schau, H.J., Muñiz Jr, A.M. and Arnould, E.J., (2009). How brand community practices create value. Journal of marketing, 73(5), 30-51.

Schouten, J.W. and McAlexander, J.H., (1995). Subcultures of consumption: An ethnography of the new bikers. Journal of consumer research, 22(1), 43-61.

Smith, M.A., (1999). Invisible crowds in cyberspace. Communities in cyberspace, (Part 1), 195-218.

Social Media Marketing Industry Report (SMMIR), (2016). How marketers are using social media to grow their businesses

Tajfel, H., and Turner, J. C. (1985). The social identity theory of intergroup behavior. In S.Worchel \& W.G.Austin (Eds.), Psychology of intergroup relations (pp. 7-24). Chicago: Nelson-Hall.

Thompson, S. and Sinha, R. (2008). Brand communities and new product adoption: the influence and limits of oppositional loyalty. Journal of Marketing, 72 (6), 65-80

Vargo, S.L. and Lusch, R.F., (2004). Evolving to a new dominant logic for marketing. Journal of marketing, 68(1), 1-17.

Vargo, S.L. and Lusch, R.F., (2008). Service-dominant logic: continuing the evolution. Journal of the Academy of marketing Science, 36(1), 1-10. 
Weber, M., (1978). Economy and society: An outline of interpretive sociology (Vol. 1). Univ of California Press.

Wang, Y. and Hajli, M.N., (2014). Co-creation in branding through social commerce: The role of social support, relationship quality and privacy concerns.

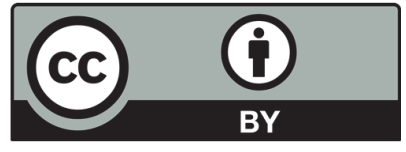

(C) 2017 by the authors; licensee Growing Science, Canada. This is an open access article distributed under the terms and conditions of the Creative Commons Attribution (CC-BY) license (http://creativecommons.org/licenses/by/4.0/). 